\title{
Carbon Dioxide as a Microbial Toxicity Enhancer of Some Antibacterial Agents: A New Potential Water Purification Tool
}

\author{
Varsik Martirosyan, ${ }^{1}$ Karlen Hovnanyan, ${ }^{2}$ and Sinerik Ayrapetyan ${ }^{1}$ \\ ${ }^{1}$ Department of Biotechnology, Life Sciences International Postgraduate Educational Center, 31 Acharyan Street, \\ 0040 Yerevan, Armenia \\ ${ }^{2}$ Laboratory of Electron Microscopy, Institute of Molecular Biology, 7 Hasratian Street, 0014 Yerevan, Armenia
}

Correspondence should be addressed to Varsik Martirosyan, varsikmartirosyan@gmail.com

Received 5 January 2012; Accepted 6 February 2012

Academic Editor: M. P. Ponomarenko

Copyright ( 2012 Varsik Martirosyan et al. This is an open access article distributed under the Creative Commons Attribution License, which permits unrestricted use, distribution, and reproduction in any medium, provided the original work is properly cited.

The aim of current paper was to investigate the possibility of increasing the toxicity of calcium hypochlorite $\left(\mathrm{Ca}(\mathrm{ClO})_{2}\right)$ and hydrogen peroxide $\left(\mathrm{H}_{2} \mathrm{O}_{2}\right)$ on Escherichia coli $\mathrm{K}-12$ by preliminary enrichment of culture media by carbon dioxide $\left(\mathrm{CO}_{2}\right)$. For this purpose, the microbes sensitivity to $\mathrm{H}_{2} \mathrm{O}_{2}$ or/and $\mathrm{Ca}(\mathrm{ClO})_{2}$ at normal and $\mathrm{CO}_{2}$-enriched medium was studied by spectrophotometric, radioisotopic, and electronmicroscopic methods. Ten-minute preincubation in $\mathrm{CO}_{2}$-enriched medium enhanced the toxic effect of both $\mathrm{H}_{2} \mathrm{O}_{2}$ or/and $\mathrm{Ca}(\mathrm{ClO})_{2}$ on bacteria as a result of induced growth inhibition, compared to no$\mathrm{CO}_{2}$ enriched group. Additionally, changes in cell morphology and proliferation were observed. It was demonstrated that the preliminary incubation of microbes in $\mathrm{CO}_{2}$-enriched culture media in nonsupercritical concentration elevate the toxic effect of $\mathrm{H}_{2} \mathrm{O}_{2}$ or/and $\mathrm{Ca}(\mathrm{ClO})_{2}$ on microbes. This can serve as a novel, effective, inexpensive, and environmentally friendly approach for water purification from bacteria, further improving the protection of the environment and human health.

\section{Introduction}

One of the global challenges of the 21 st century is to find the best method for cleanup of aquatic ecosystems from microbes, which will be cheap, safe for human health, and environmentally friendly $[1,2]$. Chlorination is one of the most widely used processes for microbial control [3] in both drinking water and wastewater processing [4]. Chlorine is a powerful antimicrobial substance due to its potential oxidizing capacity [3]. In general, disinfectants like chlorine are used in very high concentrations for the purpose of attaining a rapid rate of killing. It is difficult for microorganisms to survive in such concentrations. However, the use of the chlorine increases the risk of the formation of potentially hazardous by-products or the production of foul tastes and odors, which are the main drawbacks of chlorination [5]. Conversely, at low chlorine levels, microorganisms that survive the treatment may be injured rather than inactivated [6]. Under suitable conditions, injured cells might repair cellular damage and recover [7]. An appreciation of the nature of sublethal injury and repair is, therefore, important in devising chlorination strategies and in developing combination treatments with synergistic actions against the target microorganisms. The mechanisms of action of chlorine on microorganisms have been widely investigated [8]. Nevertheless, the mechanism by which chlorine exerts its lethal effect has never been fully elucidated.

Currently, $\mathrm{H}_{2} \mathrm{O}_{2}$ and supercritical carbon dioxide $\left(\mathrm{SCCO}_{2}\right)$ are being used as tools for water purification but separately. While the molecular mechanism of "killing" effect of $\mathrm{H}_{2} \mathrm{O}_{2}$ on bacteria is well documented [9], the mechanism of "killing" effect of $\mathrm{CO}_{2}$ on bacteria still remains discussable [10]. Although it is already documented that the combination of $\mathrm{SCCO}_{2}$ and $\mathrm{H}_{2} \mathrm{O}_{2}$ inactivates spores to high degree [11], the potential mechanism by which this inactivation takes place is still unknown. Moreover, this combination of $\mathrm{SCCO}_{2}$ and $\mathrm{H}_{2} \mathrm{O}_{2}$ has not yet been used as a water purification tool.

Our previous investigations showed 2 functionally different states of membrane proteins, active and inactive (reserve) 
in eukaryotic cells [12]. The ratio of these active and inactive molecules could be changed by the modulation of cell hydration [12-14]. It was also shown, that metabolic poisons cause cell hydration [15] resulting in the increase of the number of functionally active receptors in the membrane [12]. On the one hand, $\mathrm{CO}_{2}$, as a strong metabolic poison, that leads to the increase of cell hydration, could serve as a potential factor able to elevate membrane sensitivity to $\mathrm{H}_{2} \mathrm{O}_{2}$ or/and $\mathrm{Ca}(\mathrm{ClO})_{2}$ of microbes. Thus, it was suggested that $\mathrm{CO}_{2}$ could elevate the toxic effect of $\mathrm{H}_{2} \mathrm{O}_{2}$ or/and $\mathrm{Ca}(\mathrm{ClO})_{2}$ on cell.

Therefore, the use of the activation of microbial metabolism induced by comparatively low concentrations of $\mathrm{CO}_{2}$ to enhance the toxic effect of $\mathrm{H}_{2} \mathrm{O}_{2}$ or/and $\mathrm{Ca}(\mathrm{ClO})_{2}$ on microbes was checked. This fact and data obtained from our published patents $[16,17]$ suggest that a certain combination of both of "killer" molecules may allow the development of a novel and safe method for water purification.

\section{Materials and Methods}

2.1. Experimental Setup and Apparatus. The processing apparatus used in this work contained 50 liter $\mathrm{CO}_{2}$ vacuum tank, the airline tubing with regulator valve and the CellStar $\mathrm{CO}_{2}$ incubator (USA, Model: SWJ500TV BA). The test tubes containing $100 \mathrm{~mL}$ bacterial culture were placed in the CellStar incubator at $20^{\circ} \mathrm{C}$. Carbon dioxide (air liquid, 99.7\% purity) was injected into the individual test tubes in the incubator at the selected pressure (atmospheric pressure) for $10 \mathrm{~min}$. The corresponding non- $\mathrm{CO}_{2}$ controls were made the same way, except that the test tubes were not flushed by carbon dioxide. After 10 min of incubation, the $\mathrm{H}_{2} \mathrm{O}_{2}$ and/or $\mathrm{Ca}(\mathrm{ClO})_{2}$ in corresponding concentrations was added to the tubes, and then samples were closed and removed to thermostat at $37^{\circ} \mathrm{C}$ for $18 \mathrm{~h}$ for the future processing.

\subsection{Bacterial Strain, Culture Media, Chemicals, and Estima-} tion of the Bacterial Growth. Wild-type Escherichia coli K-12 (obtained from the Armenia Collection of Microorganisms (Institute of Microbiology of the Center of Microbiology and Microbial Depository of Armenian NAS, Yerevan)) was used for experiments. Prior to each test, the bacterial cultures (previously stored at $4^{\circ} \mathrm{C}$ in nutrient-enriched agar slants (NEA, containing: nutrient enrich broth (NEB) $+1.5 \%$ agar (Difco), final pH $7.1 \pm 0.2$ at $37^{\circ} \mathrm{C}$ ) were grown in nutrientenriched broth (NEB, containing: peptone $15 \mathrm{~g} / \mathrm{L}$, sodium chloride $6.0 \mathrm{~g} / \mathrm{L}$, yeast extracts $3.0 \mathrm{~g} / \mathrm{L}$, final $\mathrm{pH} 7.5 \pm 0.2$ at $\left.37^{\circ} \mathrm{C}\right)$, at $37^{\circ} \mathrm{C}$ in thermostat overnight $(18 \mathrm{~h})$ and used for the treatments.

For $\mathrm{H}_{2} \mathrm{O}_{2}$ and $\mathrm{Ca}(\mathrm{ClO})_{2}$ treatments, fresh hydrogen peroxide and calcium hypochlorite solutions were prepared immediately before the experiments and added to the bacterial cultures in the corresponding concentrations of the substances in aqua media. Microbial growth was evaluated spectrophotometrically at a wavelength of $600 \mathrm{~nm}$ using a CФ-46 ЛOMO spectrophotometer (Russian Federation) for $18 \mathrm{~h}$.

2.3. Electronmicroscopy Assay. The damage of microbial cells was visualized by electron-microscopy. Negative contrasting was performed using $2 \%$ phosphoric-tungsten acid solution at $\mathrm{pH}$ 6.8-7.0. Microscopic preparations of bacterial suspensions were made after the centrifugation of bacterial suspension at $3000 \mathrm{rpm}$ (CLR-1) for $10 \mathrm{~min}$, then bacterial sediment was fixed by $2.5 \%$ solution of glutaraldehyde in $0.1 \mathrm{M}$ cacodylate buffer under $\mathrm{pH} 7.4$ during $2 \mathrm{~h}$ under room temperature. After three-phase washing in $0.1 \mathrm{M}$ cacodylate buffer, the cells were fixed under room temperature by $1 \%$ of solution tetroxid osmium in $0.1 \mathrm{M}$ cacodylate buffer under $\mathrm{pH} 7.4$ during not less than $1 \mathrm{~h}$. After washing in the same buffer, dehydration of sample was conducted in the ethanol increasing concentrations for 30, 50, 70, 96 and $100 \%$ or acetone increasing concentrations and potting by mixture of Araldite on Lufft. Then the bacterial sediment was polymerized in thermostat at $37^{\circ} \mathrm{C}$ and $59^{\circ} \mathrm{C}$ in Araldite preparations. Ultrathin sections were prepared using the ultra cut "Reichert" "Ultracut-Young" and stained in the uranyl acetat and lead citrate. The sections were checked by electronic microscope Tesla BS-500 (Czechoslovakia). The photomicrographies were scanned in permit of 900 pixels for inch and processed on computer programme Corel Draw versions 11 and Photoshop versions 8. Computer morphometric and stereometric analysis of electron microscopic imaging was performed according to the program "Video Test Structure-5, nanotechnology."

2.4. Radioactive Labeled $\left[{ }^{3} \mathrm{H}\right]$-Thymidine-Based Cell Proliferation Assay. For the measurement of the cell proliferation, the bacteria cultures were grown in $100 \mathrm{~mL}$ of $\mathrm{NEB}$ at $37^{\circ} \mathrm{C}$ overnight. One $\mathrm{mL}$ of overnight culture $\left(10^{10}\right.$ cells $)$ was added to the $30 \mathrm{~mL}$ NEB (containing $40 \mathrm{~mL}\left[{ }^{3} \mathrm{H}\right]$-thymidine $(1.3 \mu \mathrm{Ci} / \mathrm{mL})\left(\left[6-{ }^{3} \mathrm{H}\right]\right.$-thymidine, PerkinElmer, Boston, $\mathrm{MA}$, $14.4 \mathrm{Ci} / \mathrm{mmol}$ specific activity)). $\left[{ }^{3} \mathrm{H}\right]$-thymidine containing samples were treated by $\mathrm{CO}_{2}, \mathrm{H}_{2} \mathrm{O}_{2}, \mathrm{CO}_{2} / \mathrm{H}_{2} \mathrm{O}_{2}$, and $\mathrm{CO}_{2} / \mathrm{Ca}(\mathrm{ClO})_{2}$ and then incubated in thermostat at $37^{\circ} \mathrm{C}$, for $18 \mathrm{~h} .\left[{ }^{3} \mathrm{H}\right]$-thymidine uptake was stopped by precipitation of each portion with ice-cold $10 \%$ trichloroacetic acid (TCA). The cells were harvested by centrifugation for $10 \mathrm{~min}$ at $5000 \mathrm{~g}$ and washed 2 times by TCA and then again harvested by centrifugation. Then $3 \mathrm{~mL}$ of Bray's scintillation cocktail was added to each sample, and the radioactivity was measured by using a Wallac 1450 liquid scintillation counter.

2.5. Statistical Analysis. Statistical analyses were conducted by SPSS 17 software. The differences among the means of treatment were tested by using the paired sample $t$-test. All experiments were repeated at least three times. Values are shown as means \pm std. error.

\section{Results}

3.1. Effect of the Antibacterial Properties of $\mathrm{CO}_{2} / \mathrm{H}_{2} \mathrm{O}_{2} \mathrm{Com}$ bination on the Growth of E. coli K-12. The response of $E$. coli to $\mathrm{H}_{2} \mathrm{O}_{2}$ is dose dependent, with production of different oxidative species as a result of cell exposure to different concentrations of the oxidant. Two different mechanisms of cell death are possible: at low concentrations microbes are forming filaments, while at higher concentrations microbes are shrinking $[9,18,19]$. In the current study, we have 


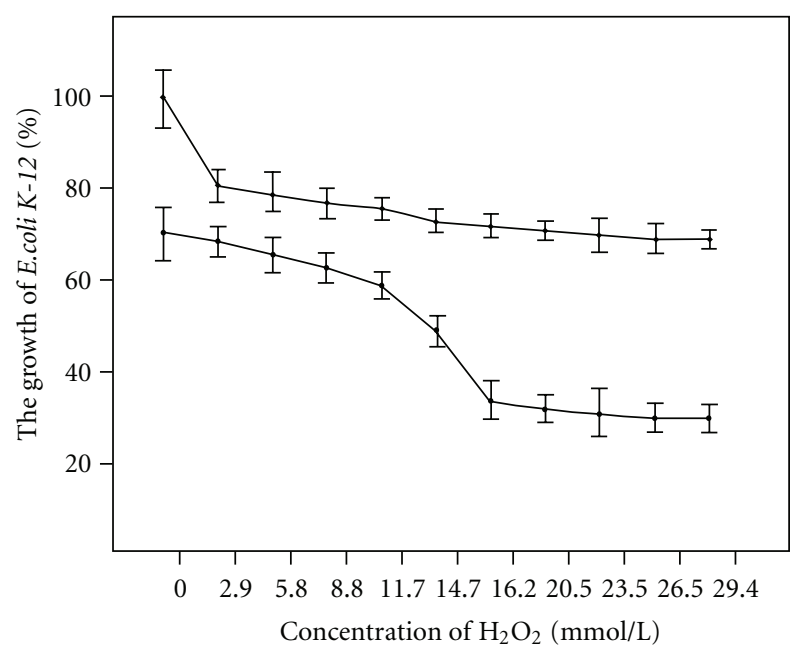

Figure 1: The effect of different concentrations of $\mathrm{H}_{2} \mathrm{O}_{2}$ (mmol/L) on the growth of E. coli $\mathrm{K}-12$ (\%) in $10 \mathrm{~min} \mathrm{CO}_{2}$-enriched bathing medium $(\bullet)$ and in case of non- $\mathrm{CO}_{2}$-enriched bathing medium $(\checkmark)$. The samples were compared with control one (100\% growth), which does not contain the carbon dioxide and hydrogen peroxide. $\left.P=0.01{ }^{* *}\right), n=3$.

checked the potential of elevation of the toxic effect of comparatively low doses of $\mathrm{H}_{2} \mathrm{O}_{2}$ on microbes by preliminary increase of the metabolic activity of microbes using preincubation of the latter in the aqua medium enriched with $\mathrm{CO}_{2}$ (10 min). Since $\mathrm{CO}_{2}$ dissolves in aqueous solutions, forming an acid and lower the $\mathrm{pH}$, to avoid the additional effects of these, the $\mathrm{pH}$ was adjusted to the constant 6.0, supporting the maximal growth of E. coli [20] by addition of $\mathrm{NaOH}(0.1 \mathrm{~mol} / \mathrm{L})$ during $\mathrm{CO}_{2}$ treatment.

The toxic effect of low concentrations of $\mathrm{H}_{2} \mathrm{O}_{2}$ on E. coli $\mathrm{K}-12$ was increased in cell growth medium enriched with $\mathrm{CO}_{2}$ for 10 min (maximum) (Figure $1,(\bullet)$ ), compared to non- $\mathrm{CO}_{2}$ enriched medium (Figure $\left.1,(\checkmark)\right)$.

3.2. Effect of the Antibacterial Properties of $\mathrm{CO}_{2} / \mathrm{Ca}(\mathrm{ClO})_{2}$ Combination on the Growth of E. coli K-12. The response of $E$. coli to chlorine highly depends on its concentration $[21,22]$. As the aim of present work is to find out the possibility of the modulation of the effect of $\mathrm{CO}_{2}$ on the toxic effect of relatively low doses of chlorine on microbes, the dose-dependent effect of $\mathrm{Ca}(\mathrm{ClO})_{2}(\mathrm{mg} / \mathrm{L})$ on the growth of E. coli $\mathrm{K}-12$ in normal and after $10 \mathrm{~min}$ incubation microbes in $\mathrm{CO}_{2}$-enriched culture medium was studied (Figure 2).

Preliminary treatment by $\mathrm{CO}_{2}$ enhanced the "killing effect of $\mathrm{Ca}(\mathrm{ClO})_{2}$ on the bacteria observed in all checked $\mathrm{Ca}(\mathrm{ClO})_{2}$ concentrations. However, this effect was more pronounced at low concentration of $\mathrm{Ca}(\mathrm{ClO})_{2}(>0.1 \mathrm{mg} / \mathrm{L})$ and decreased parallel to the concentration increase up to constant level, about $15 \%$. These data suggests the existence of the minimum two pathways through which the $\mathrm{CO}_{2}$ could potentiate the toxic effect of chlorine. The observed $\mathrm{CO}_{2}-$ induced enhancement of $\mathrm{Ca}(\mathrm{ClO})_{2}$ toxicity at low doses can be explained by $\mathrm{CO}_{2}$-induced stimulation of oxidative metabolisms, which is a target for poisoning effect of

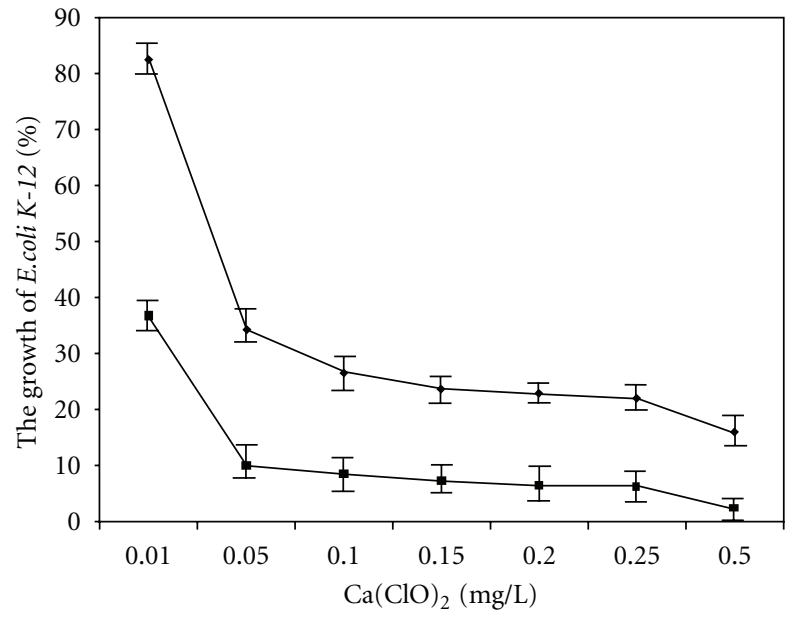

Figure 2: The dose-dependent effect of $\mathrm{Ca}(\mathrm{ClO})_{2}(\mathrm{mg} / \mathrm{L})$ on the growth of E. coli $\mathrm{K}-12(\%)$ in 10 min $\mathrm{CO}_{2}$-enriched bathing medium $(\boldsymbol{\square})$ and in case of non- $\mathrm{CO}_{2}$-enriched bathing medium $(\boldsymbol{\nabla})$. The $P$ value of the treatments was $0.01(* *)$. The samples were compared with control one $(100 \%$ growth), which does not contain the chlorine and carbon dioxide. The number of experiments was three.

$\mathrm{Ca}(\mathrm{ClO})_{2}$. Probably the $\mathrm{CO}_{2}$-induced poisoning effect of $\mathrm{Ca}(\mathrm{ClO})_{2}$ is a reason for the increase of the number of cellular targets (receptors) for $\mathrm{Ca}(\mathrm{ClO})_{2}$ attack. Our previous work showed that cell swelling, probably the result of cell metabolism poisoning, could serve as one of such pathways [13]. Therefore, according to the fact that $\mathrm{CO}_{2}$ is metabolic poison, there is theoretical possibility that $\mathrm{CO}_{2}$-induced cell swelling could serve as a mechanism responsible for the increase of microbes' sensitivity to $\mathrm{Ca}(\mathrm{ClO})_{2}$.

3.3. Electronmicroscopic Study of $\mathrm{CO}_{2}, \mathrm{H}_{2} \mathrm{O}_{2}$, and $\mathrm{Ca}(\mathrm{ClO})_{2}$ Effects on E. coli $K-12$. Electron-microscopic study of the untreated E. coli $\mathrm{K}-12$ culture showed that cells have an ultrastructure, typical for gram-negative bacteria (Figures $3(\mathrm{a})$ and 3(b)). Ultrastructural analysis of $E$. coli $\mathrm{K}-12$ has showed that effect of different biocides, such as $\mathrm{CO}_{2}, \mathrm{H}_{2} \mathrm{O}_{2}$, or/and $\mathrm{Ca}(\mathrm{ClO})_{2}$, leads to the ultrastructural changes in membranes, cytoplasm, and nucleotide. Treatment by $\mathrm{CO}_{2}$ leads to the destruction of cellular wall and the removal of external membrane of wall of bacteria (Figures 4(a), 4(b), 5(a), 5(b), and 5(c)). An addition to the similar effect of $\mathrm{H}_{2} \mathrm{O}_{2}$ and its derivatives, for example, removal of external membrane of wall, increase of the transparency of citoplasmatic membrane was also demonstrated (Figures $6(\mathrm{a})$ and $6(\mathrm{~b}))$. The treatment of $E$. coli $\mathrm{K}-12$ by $\mathrm{Ca}(\mathrm{ClO})_{2}$ destructs the cellular wall, which leaves from citoplasmatic membrane. Moreover, the cytoplasm had small granular structures (Figures 7(a) and 7(b)).

3.4. Radioactive Labeled $\left[{ }^{3} \mathrm{H}\right]$-Thymidine-Based Cell Proliferation Assay. The measurement of the cell proliferation using radioactive $\left[{ }^{3} \mathrm{H}\right]$-thymidine assay has shown inhibition effects in all cases of treatments. The $\mathrm{CO}_{2}$ treatment alone inhibited the cell proliferation by $49 \%$ compared to the 


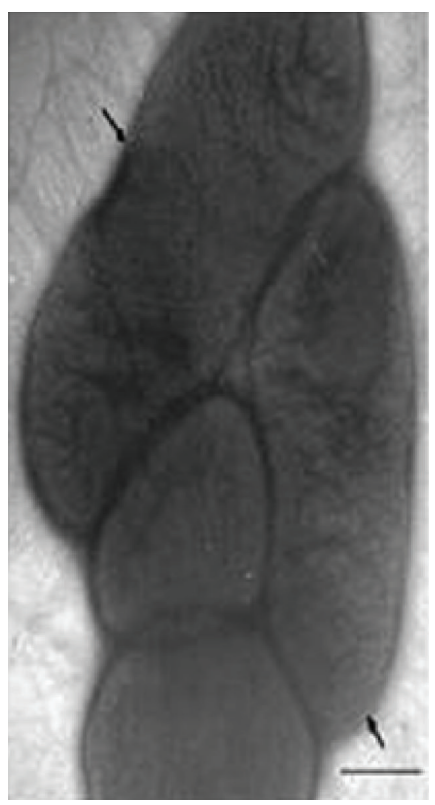

(a)

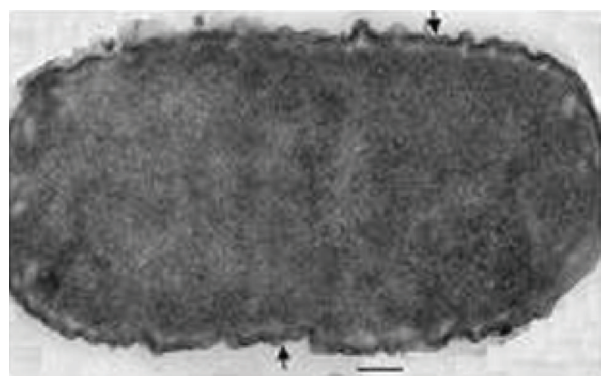

(b)

Figure 3: Transmission of electronmicroscopy (TEM). Intact cell of E. coli K-12: (a) negative staining and (b) ultrathin section. Scale bar (a, b) $=1 \mu \mathrm{m}$.

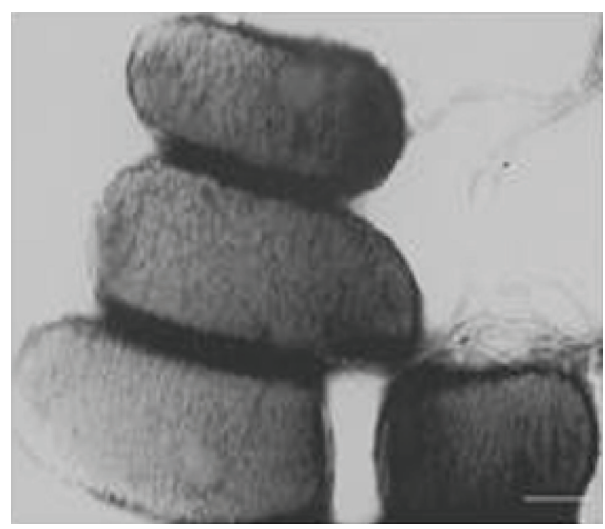

(a)

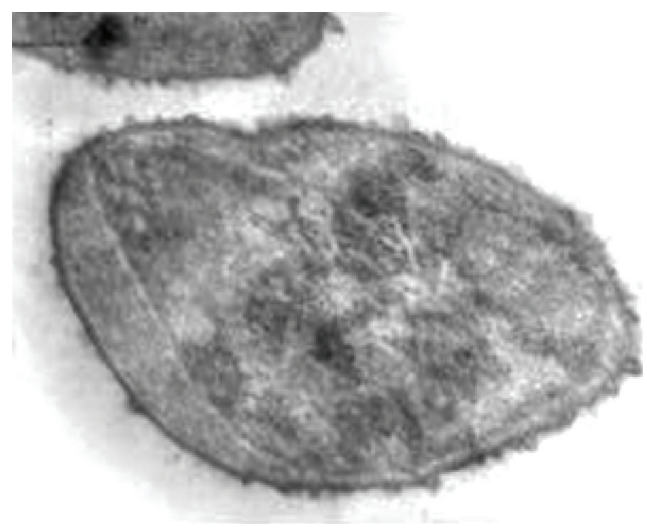

(b)

Figure 4: TEM. The action of $\mathrm{CO}_{2}$ on the E. coli $\mathrm{K}-12$. Negative staining (a). Ultrathin section (b): the external membrane of the cellular wall with expansion of the periplasmatic dimension has been taken. Scale bar $(\mathrm{a}, \mathrm{b})=1 \mu \mathrm{m}$.

control group. $\mathrm{H}_{2} \mathrm{O}_{2}$ alone inhibited the proliferation by $27 \%$ and its combination with $\mathrm{CO}_{2}\left(\mathrm{CO}_{2} / \mathrm{H}_{2} \mathrm{O}_{2}\right)$ showed the proliferation decrease by $68 \%, \mathrm{Ca}(\mathrm{ClO})_{2}$ inhibited the proliferation by $19 \%$, but the combined effect of $\mathrm{CO}_{2} / \mathrm{Ca}(\mathrm{ClO})_{2}$ couple showed higher inhibition of $30 \%$ inhibition effect (Figure 8).

\section{Discussion}

The search for novel alternatives of water disinfection is of immense interest, and much effort is concentrated to address this issue. The current paper suggests a novel tool for enhancement of the efficiency of the two most common disinfecting agents, such as $\mathrm{H}_{2} \mathrm{O}_{2}$ and $\mathrm{Ca}(\mathrm{ClO})_{2}$ by combing them with $\mathrm{CO}_{2}$.
Our data clearly showed that $\mathrm{CO}_{2}$ increased the toxic effect of $\mathrm{H}_{2} \mathrm{O}_{2}$ and/or $\mathrm{Ca}(\mathrm{ClO})_{2}$ on microbes, and it could be used as a promising tool for water purification.

As the toxic effect of $\mathrm{H}_{2} \mathrm{O}_{2}$ [19] and $\mathrm{Ca}(\mathrm{ClO})_{2}$ [23] is realized by its oxidative properties, consequently, their inhibition effects depend on the initial metabolic activity of microbes. It is suggested that the factor having stimulatory effect on cell metabolism could enhance the toxic effect of $\mathrm{H}_{2} \mathrm{O}_{2}$ and/or $\mathrm{Ca}(\mathrm{ClO})_{2}$ on microbes.

On the basis of the fact that $\mathrm{CO}_{2}$ at comparatively low concentrations [10] has strong stimulatory effect on cell metabolism, it could be suggested that cells pretreated by $\mathrm{CO}_{2}$ could have high sensitivity to toxic effect of $\mathrm{H}_{2} \mathrm{O}_{2}$ (Figure 1) and $\mathrm{Ca}(\mathrm{ClO})_{2}$ (Figure 2). It should be mentioned that stimulation of growth occurs because some anabolic 


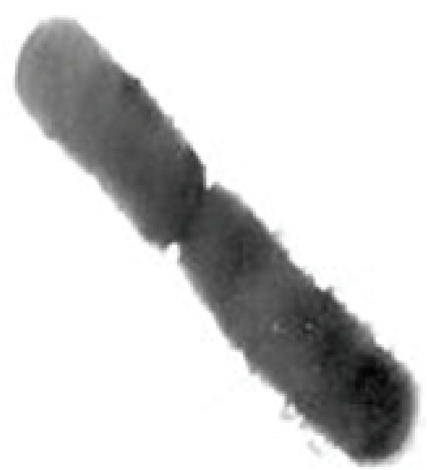

(a)

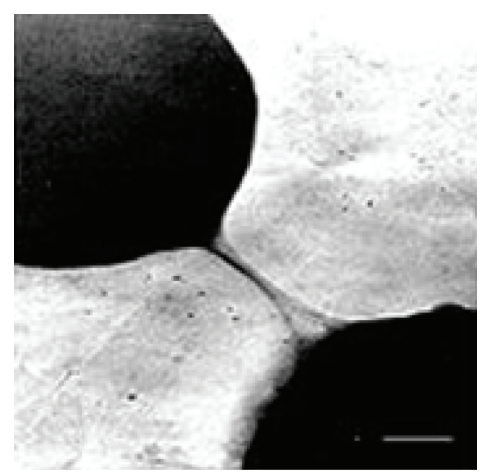

(b)

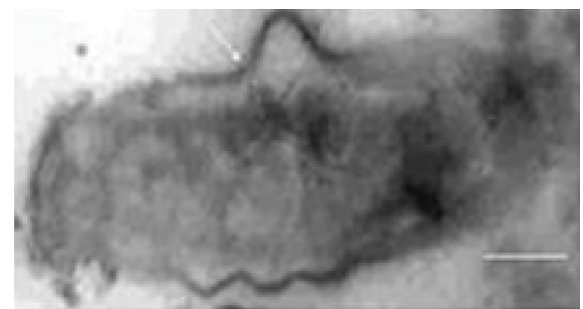

(c)

FIgURE 5: TEM. Action of $\mathrm{CO}_{2}$ on E. coli K-12: (a) negative contrasting, (b) the inner cellular contact with the external membrane of cellular wall of E. coli, (c) ultrathin section. Scale bar $=1 \mu \mathrm{m}(\mathrm{a}, \mathrm{b}, \mathrm{c})$.

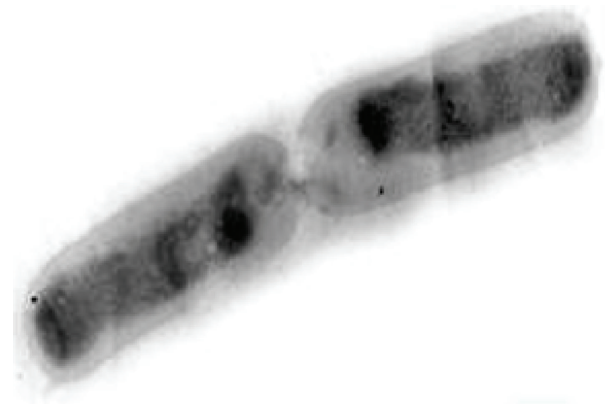

(a)

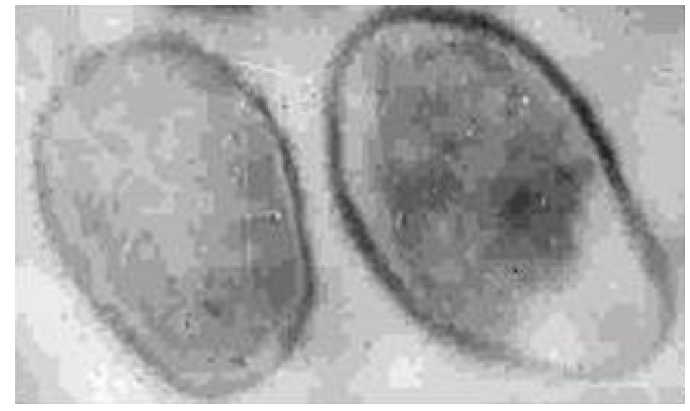

(b)

Figure 6: TEM. The effects of $\mathrm{H}_{2} \mathrm{O}_{2}$ on E. coli K-12. Negative contrasting (a) and ultrathin section (b): the external membrane cellular wall with expansion of periplasmatic space has been taken. Scale bar $(\mathrm{a}, \mathrm{b})=1 \mu \mathrm{m}$.

reactions involve $\mathrm{CO}_{2}$ fixation, and in the absence of an external source of the gas, $\mathrm{CO}_{2}$ concentration in cell can be rate limiting for these reactions, with resultant decreased growth rates [10]. The basis of $\mathrm{CO}_{2}$ inhibition has not been clearly established.

Carbon dioxide has a dual physiological role in microorganisms since it can both stimulate and inhibit cell development [24]. Various hypotheses have been proposed to explain the microbicidal activity of carbon dioxide. $\mathrm{CO}_{2}$ dissolves in water to form carbonic acid. Thus, dissolved $\mathrm{CO}_{2}$ acts by lowering the $\mathrm{pH}$ of the medium, and the resulting acidity leads to a disturbance of some biological systems within cells. It was, therefore, suggested that microbial inhibition was due to an alteration in the properties of cell (membrane, cytoplasm, enzymes, etc.) [25]. However, the reduction in the $\mathrm{pH}$ of the medium is not sufficient to account for the antimicrobial action of $\mathrm{CO}_{2}$, since it shows a specific inhibitory effect, which is greater than that of the other acids used to lower medium acidity (hydrochloric acid, phosphoric acid, etc.). These acids do not penetrate the microbial cells as easily as carbon dioxide [26]. Therefore, it was suggested that the comparatively low concentration of $\mathrm{CO}_{2}$-induced activation of the metabolism of microbes could serve as a convenient method for the increase of the sensitivity of microbes to the toxic effect of low concentration of $\mathrm{H}_{2} \mathrm{O}_{2}$ and/or $\mathrm{Ca}(\mathrm{ClO})_{2}$.
The data obtained in the current study demonstrated that the toxic effect of $\mathrm{H}_{2} \mathrm{O}_{2}$ and/or $\mathrm{Ca}(\mathrm{ClO})_{2}$ on E. coli $\mathrm{K}-12$ increased significantly when cell bathing medium was enriched with $\mathrm{CO}_{2} 10 \mathrm{~min}$ beforehand. The combination effect of $\mathrm{CO}_{2} / \mathrm{H}_{2} \mathrm{O}_{2}$ and $\mathrm{CO}_{2} / \mathrm{Ca}(\mathrm{ClO})_{2}$ was higher than in case of $\mathrm{CO}_{2}, \mathrm{H}_{2} \mathrm{O}_{2}$, and $\mathrm{Ca}(\mathrm{ClO})_{2}$ treatments separately. It is also important to mention that combined inhabitation effect of $\mathrm{CO}_{2} / \mathrm{H}_{2} \mathrm{O}_{2}(68 \%)$ is more higher than combined inhibition effect of $\mathrm{CO}_{2} / \mathrm{Ca}(\mathrm{ClO})_{2}(30 \%)$.

Although our data did not allow us to make final conclusion on the nature of the mechanism through which the $\mathrm{CO}_{2}$ poisoning metabolism could increase cell membrane sensitivity to $\mathrm{H}_{2} \mathrm{O}_{2}$ and/or $\mathrm{Ca}(\mathrm{ClO})_{2}$, it was comparable to the reported $\mathrm{CO}_{2}$-induced swelling of microbes [27]. This suggests that the $\mathrm{CO}_{2}$-induced cell hydration could serve as one of fundamental mechanisms responsible for $\mathrm{CO}_{2}$-induced enhancement of the toxic effect of these substances, which can be realized in two ways: increasing the number of membrane chemoreceptors [12] and activating intracellular macromolecules (folding) activity [14].

Additionally, the electronmicroscopic measurement of cell volume in the above-mentioned conditions demonstrated that the cell swelling is not the only mechanism through which the cell inhibition is realized by $\mathrm{CO}_{2} / \mathrm{H}_{2} \mathrm{O}_{2}$ and $\left.\mathrm{CO}_{2} / \mathrm{Ca} / \mathrm{ClO}\right)_{2}$. It is suggested that the ultrastructural visualizations could provide valuable data for correction of 


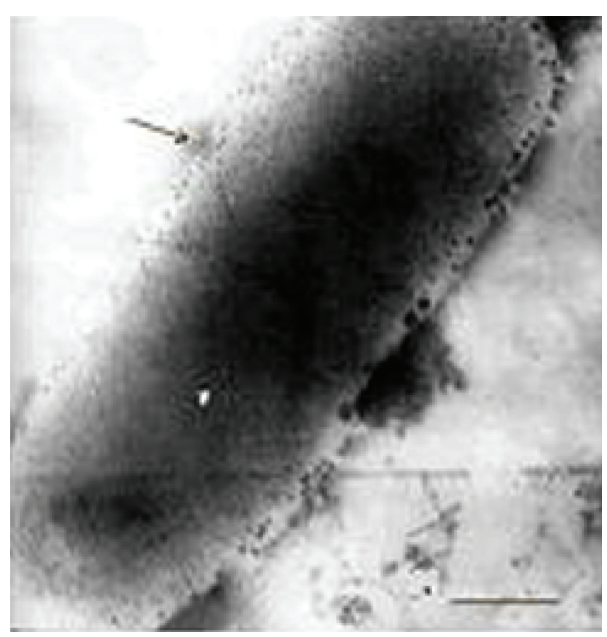

(a)

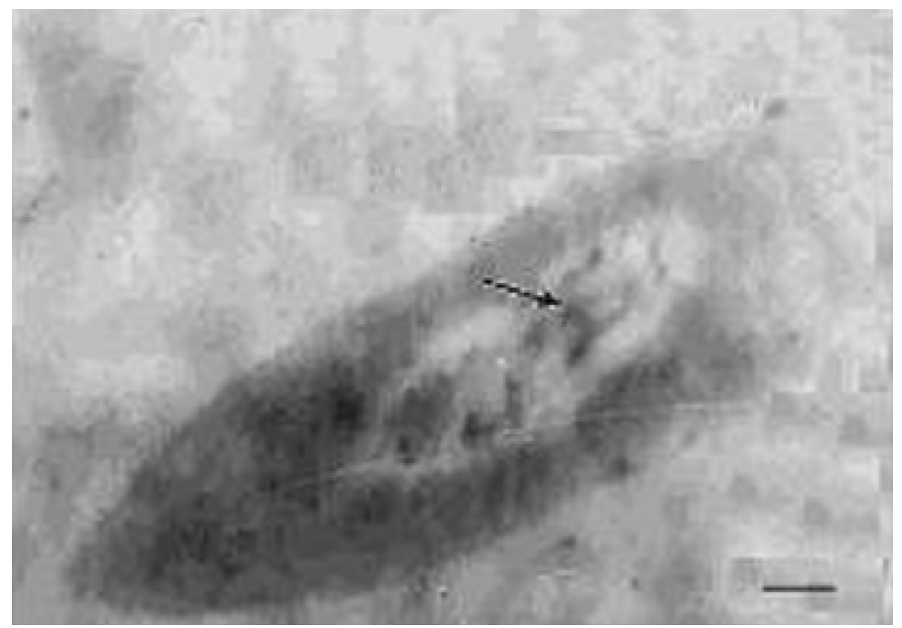

(b)

Figure 7: TEM. The effects of $\mathrm{Ca}(\mathrm{ClO})_{2}$ on E. coli K-12. Negative contrasting (a) and ultrathin section (b): the external membrane cellular wall with expansion of periplasmatic space has been taken. Scale bar $(a, b)=1 \mu \mathrm{m}$.

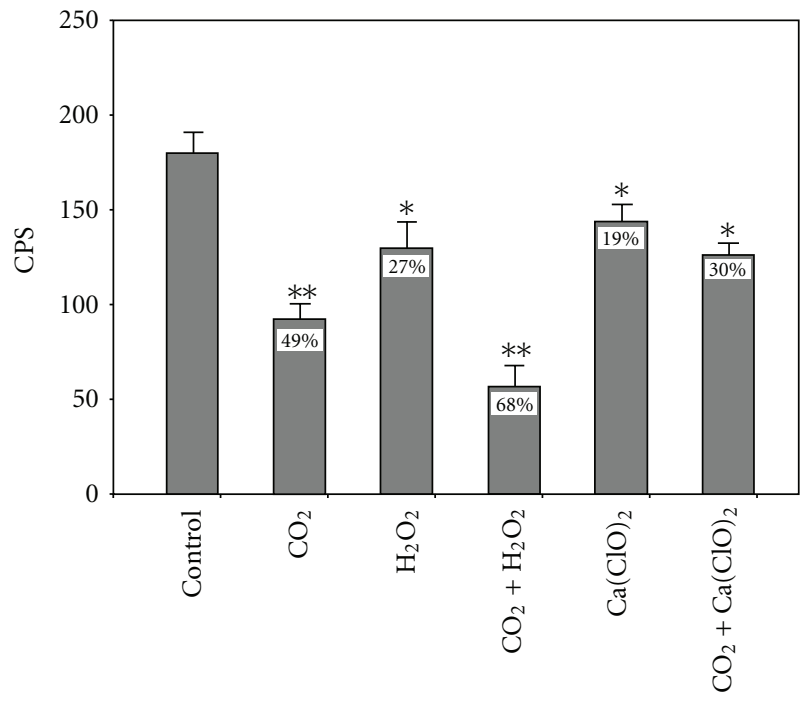

FIGURE 8: The measurement of the bacterial cell proliferation in different treatments by using radioactive labeled $\left[{ }^{3} \mathrm{H}\right]$-thymidine. Values shown in the graph are the means of three experiments \pm Std. Error.

cytopathologic characteristics of mechanism of actions of $\mathrm{CO}_{2}, \mathrm{H}_{2} \mathrm{O}_{2}$, and $\mathrm{Ca}(\mathrm{ClO})_{2}$ biocides on the bacterial culture.

The main conclusion that is drawn from the conducted studies so far is that the noncritical concentration of $\mathrm{CO}_{2}$ elevate the toxic effect of $\mathrm{H}_{2} \mathrm{O}_{2}$ and/or $\mathrm{Ca}(\mathrm{ClO})_{2}$ on E. coli K-12.

The current paper proves grounds for a new approach for decreasing microbial pollution in water, as well as for better understanding of the fundamental mechanisms controlling the microbial growth inhibition depending on environmental factors. We believe that this work will represent the first systematic investigation of the effect of $\mathrm{CO}_{2} / \mathrm{H}_{2} \mathrm{O}_{2}$ and
$\mathrm{CO}_{2} / \mathrm{Ca}(\mathrm{ClO})_{2}$ combination at comparatively low concentrations on the reduction of microbial pollution of water. The suggested method will be free from the most negative properties of water purification methods, which are currently in use.

\section{Acknowledgment}

The authors express our gratitude to Ms. Ruzanna Harutyunyan for her technical assistance.

\section{References}

[1] A. Mokrini, D. Ousse, and S. Esplugas, "Oxidation of aromatic compounds with UV radiation/ozone/hydrogen peroxide," Water Science and Technology, vol. 35, no. 4, pp. 95-102, 1997.

[2] J. Wesley Eckenfelder, "The role of chemical oxidation in waste water treatment process, chemical oxidation technologies for the nineties," Water Environment and Technology, pp. 1-4, 1992.

[3] K. L. Kotula, A. W. Kotula, B. E. Rose, C. J. Pierson, and M. Camp, "Reduction of aqueous chlorine by organic material," Journal of Food Protection, vol. 60, no. 3, pp. 276-282, 1997.

[4] M. Sisti, A. Albano, and G. Brandi, "Bactericidal effect of chlorine on motile Aeromonas spp. in drinking water supplies and influence of temperature on disinfection efficacy," Letters in Applied Microbiology, vol. 26, no. 5, pp. 347-351, 1998.

[5] S. D. Richardson, A. D. Thruston, T. V. Caughran, T. W. Collette, K. S. Patterson, and B. W. Lykins, "Chemical byproducts of chlorine and alternative disinfectants," Food Technology, vol. 52, no. 4, pp. 58-61, 1998.

[6] J. T. Lisle, S. C. Broadaway, A. M. Prescott, B. H. Pyle, C. Fricker, and G. A. Mcfeters, "Effects of starvation on physiological activity and chlorine disinfection resistance in Escherichia coli O157:H7," Applied and Environmental Microbiology, vol. 64, no. 12, pp. 4658-4662, 1998.

[7] B. Mackey, "Injured bacteria," in The Microbiological Safety and Quality of Foods, B. Lund, T. Baird-Parker, and G. Gould, Eds., pp. 315-341, Aspen Publishers, Gaithersburg, Md, USA, 2000. 
[8] C. Venkobachar, L. Iyengar, and A. V. S. P. Rao, "Mechanism of disinfection: effect of chlorine on cell membrane functions," Water Research, vol. 11, no. 8, pp. 727-729, 1977.

[9] G. Brandi, M. Fiorani, C. Pierotti, A. Albano, F. Cattabeni, and O. Cantoni, "Morphological changes in Escherichia coli cells exposed to low or high concentrations of hydrogen peroxide," Microbiology and Immunology, vol. 33, no. 12, pp. 991-1000, 1989.

[10] H. Kumagai, C. Hata, and K. Nakamura, " $\mathrm{CO}_{2}$ sorption by microbial cells and sterilization by high-pressure $\mathrm{CO}_{2}$," Bioscience, Biotechnology and Biochemistry, vol. 61, no. 6, pp. 931-935, 1997.

[11] J. Zhang, N. Dalal, M. A. Matthews et al., "Supercritical carbon dioxide and hydrogen peroxide cause mild changes in spore structures associated with high killing rate of Bacillus anthracis," Journal of Microbiological Methods, vol. 70, no. 3, pp. 442-451, 2007.

[12] S. N. Ayrapetyan and V. L. Arvanov, "On the mechanism of the electrogenic sodium pump dependence of membrane chemosensitivity," Comparative Biochemistry and Physiology, vol. 64, no. 4, pp. 601-604, 1979.

[13] S. Ayrapetyan, "On the physiological significance of the pump-induced cell volume changes," Advances in Psychological Science, vol. 23, pp. 67-82, 1980.

[14] V. A. Parsegian, R. P. Rand, and D. C. Rau, "Osmotic stress, crowding, preferential hydration, and binding: a comparison of perspectives," Proceedings of the National Academy of Sciences of the United States of America, vol. 97, no. 8, pp. 39873992, 2000.

[15] S. N. Ayrapetyan and M. A. Sulejmanian, "On the pumpinduced cell volume changes," Comparative Biochemistry and Physiology, vol. 64, no. 4, pp. 571-575, 1979.

[16] S. Ayrapetyan, Eh. Moosavi, and V. Martirosyan, "New method for water purification from microbes," Patent \# 2357A, 2010, http://www.aipa.am/upload/File/Texekagir/2010_3.pdf.

[17] V. Martirosyan and S. Ayrapetyan, "Water purification method," Patent AM20100077, 2011.

[18] N. R. Asad, L. M. B. O. Asad, A. B. Silva, I. Felzenszwalb, and A. C. Leitão, "Hydrogen peroxide effects in Escherichia coli cells," Acta Biochimica Polonica, vol. 45, no. 3, pp. 677-690, 1998.

[19] A. Hegde, G. Bhat, and S. Mallya, "Effect of exposure to hydrogen peroxide on the virulence of Escherichia coli," Indian Journal of Medical Microbiology, vol. 26, no. 1, pp. 25-28, 2008.

[20] K. A. Presser, D. A. Ratkowsky, and T. Ross, "Modelling the growth rate of Escherichia coli as a function of $\mathrm{pH}$ and lactic acid concentration," Applied and Environmental Microbiology, vol. 63, no. 6, pp. 2355-2360, 1997.

[21] R. Virto, P. Mañas, I. Álvarez, S. Condon, and J. Raso, "Membrane damage and microbial inactivation by chlorine in the absence and presence of a chlorine-demanding substrate," Applied and Environmental Microbiology, vol. 71, no. 9, pp. 5022-5028, 2005.

[22] M. Cho, J. Kim, J. Y. Kim, J. Yoon, and J. H. Kim, "Mechanisms of Escherichia coli inactivation by several disinfectants," Water Research, vol. 44, no. 11, pp. 3410-3418, 2010.

[23] J. A. Imlay, S. M. Chin, and S. Linn, “Toxic DNA damage by hydrogen peroxide through the fenton reaction in vivo and in vitro," Science, vol. 240, no. 4852, pp. 640-642, 1988.

[24] C. Wei, M. Balaban, S. Fernando, and A. Peplow, "Bacterial effect of high pressure $\mathrm{CO}_{2}$ treatment on foods spiked with Listeria or Salmonella," Journal of Food Protection, vol. 54, pp. 189-193, 1991.
[25] N. M. Dixon and D. B. Kell, "The inhibition by $\mathrm{CO}_{2}$ of the growth and metabolism of micro-organisms," Journal of Applied Bacteriology, vol. 67, no. 2, pp. 109-136, 1989.

[26] J. King and L. Mabbitt, "Preservation of raw milk by the addition of carbon dioxide," Journal of Dairy Research, vol. 49, pp. 439-447, 1982.

[27] E. Debs-Louka, N. Louka, G. Abraham, V. Chabot, and K. Allaf, "Effect of compressed carbon dioxide on microbial cell viability," Applied and Environmental Microbiology, vol. 65, no. 2, pp. 626-631, 1999. 

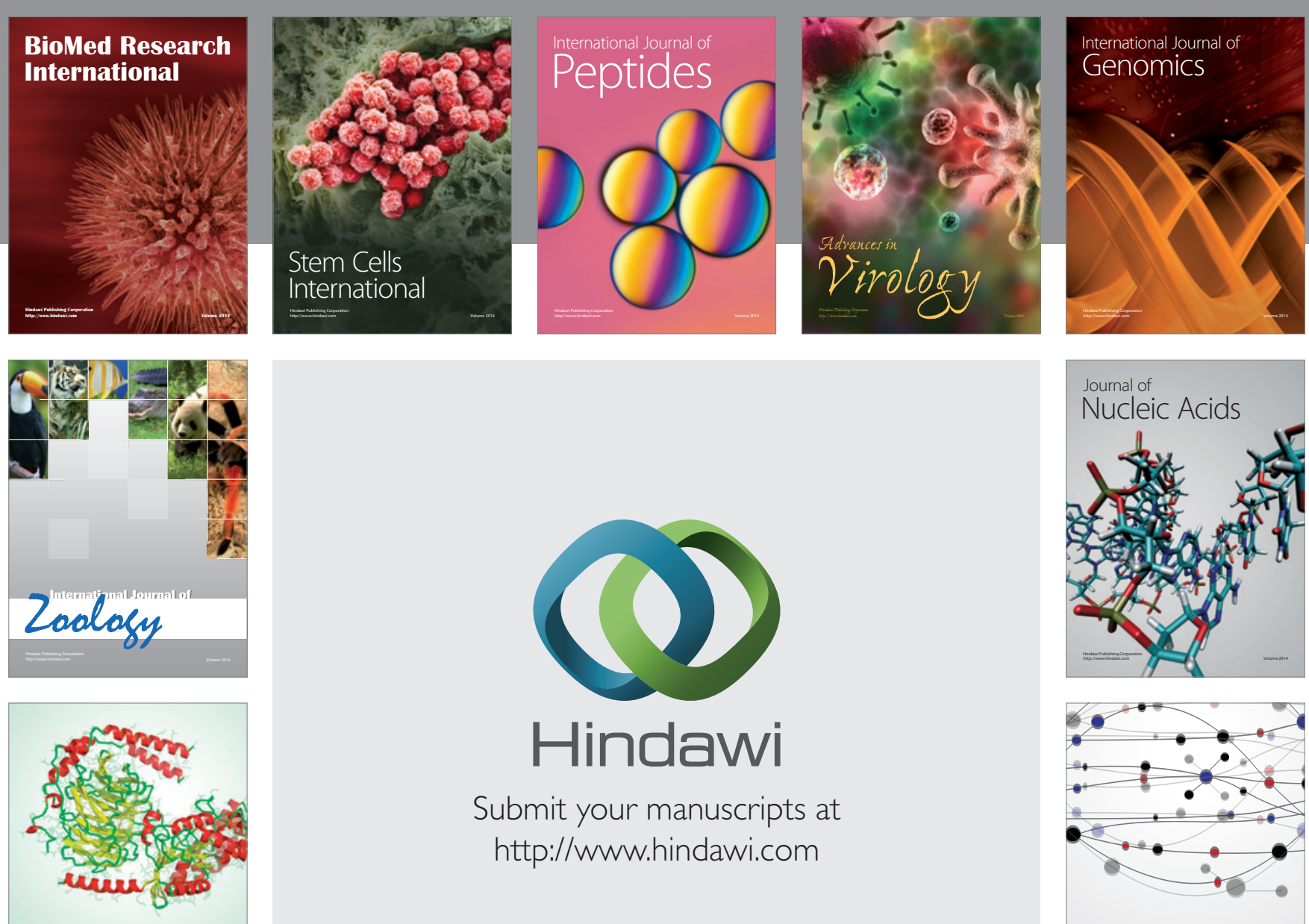

Submit your manuscripts at

http://www.hindawi.com

Signal ${ }^{\text {Jumal }}$ Transduction
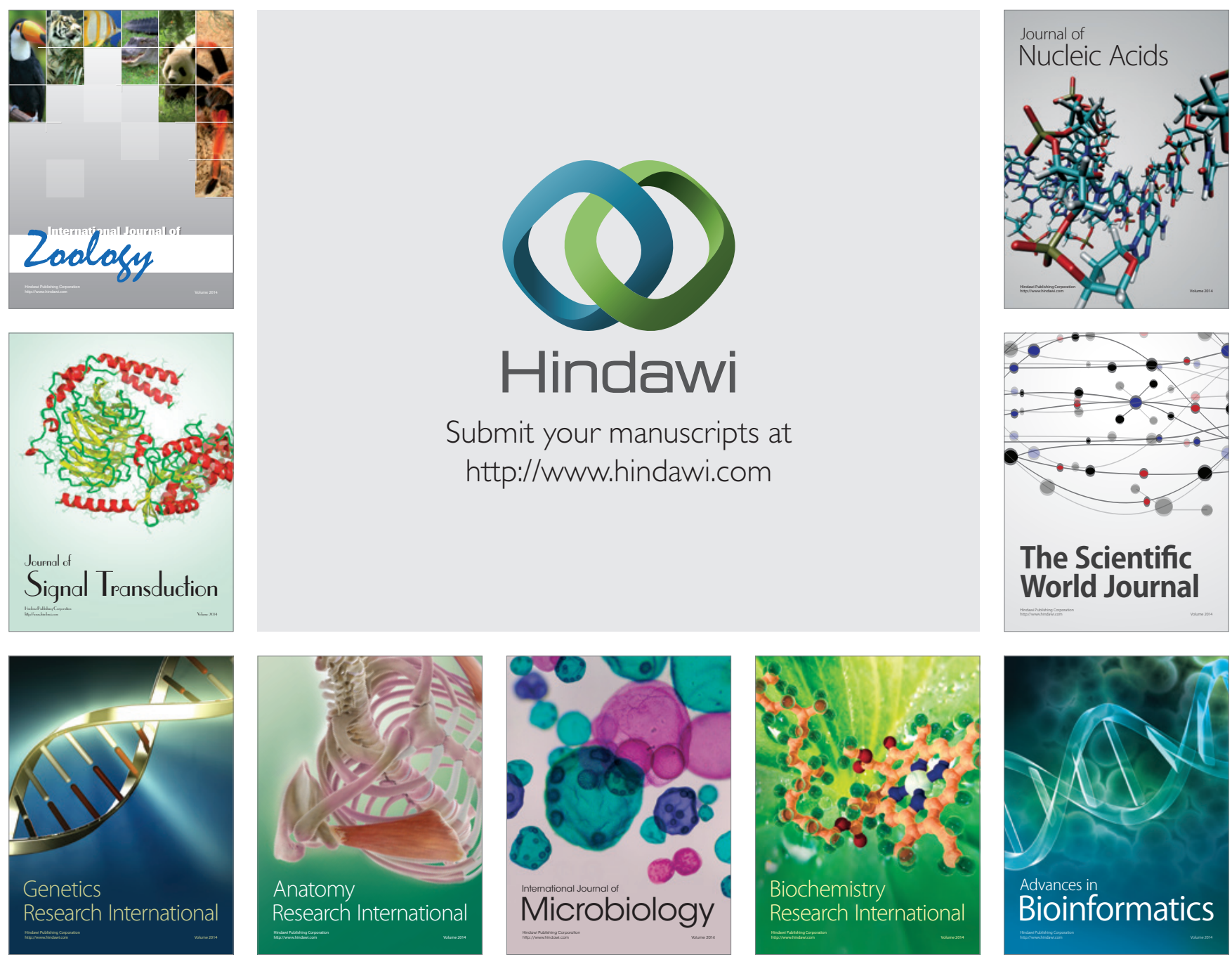

The Scientific World Journal
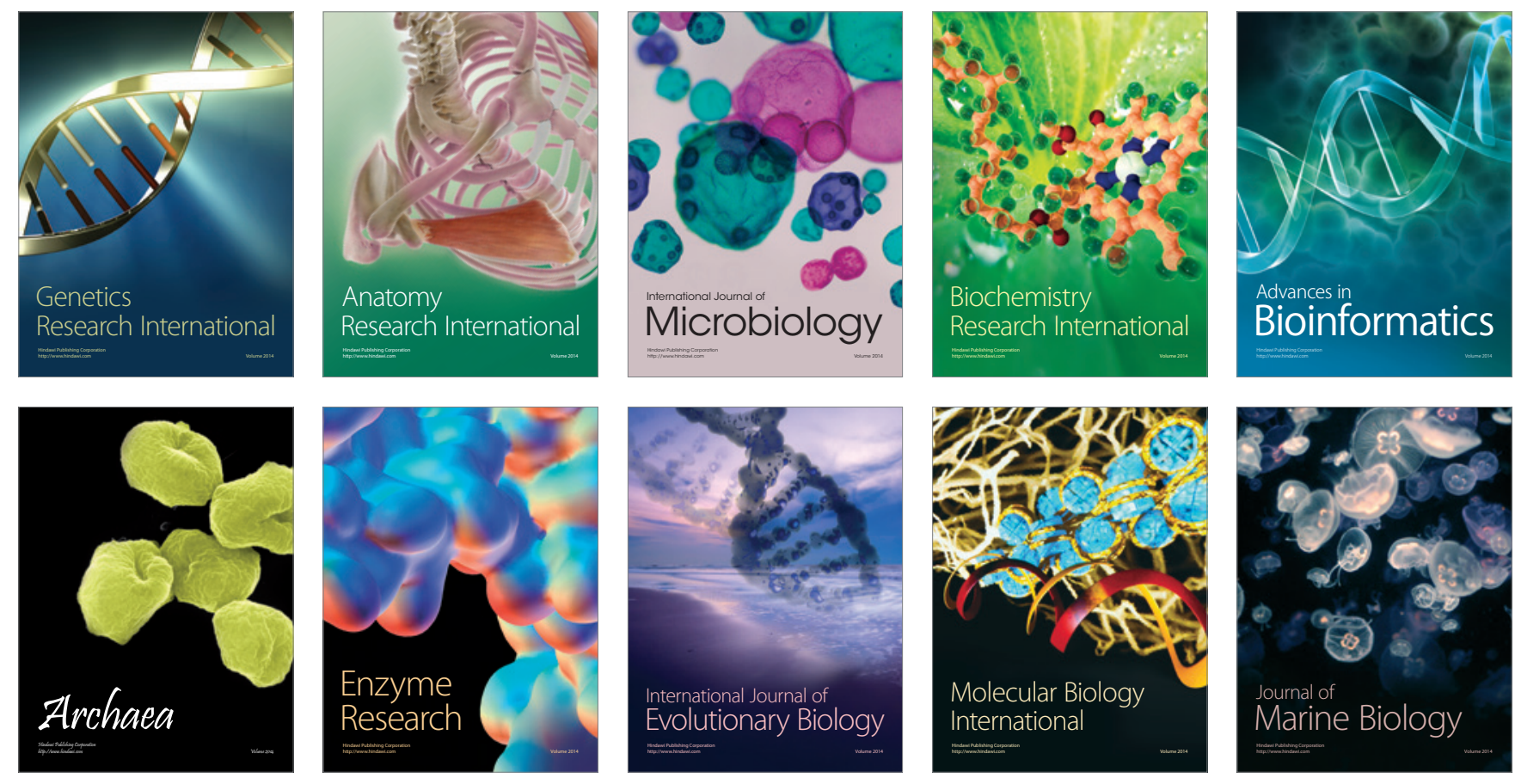